\title{
A Proposed California Statute Compensating Innocent Improvers of Realty
}

$\mathrm{O}$ $\mathrm{NE}$ who by innocent mistake improves the personal property of another, believing it to be his own, occupies a favored position under the California law. Under certain circumstances he is given the privilege of acquiring title to the article upon paying the owner its value in its unimproved state; in others he is reimbursed to the extent that his labor or materials have added value to the article. Since January 1, 1873, sections 1025 et seq. of the Civil Code, which were taken almost verbatim from the Code Napoleon, ${ }^{1}$ have effected this decided change from the severity of the common law doctrine which left the improver remediless in many cases. ${ }^{2}$ Surprisingly, however, the common law rule refusing compensation still obtains in California as to the innocent improver of real property. Section 1013 of the Civil Code following the common law maxim, quicquid plantatur solo, solo cedit, provides that property affixed to the land of another without an agreement permitting its removal belongs to the owner of the land. Where damages for the withholding of the property are claimed by the owner, section 741 of the Code of Civil Procedure permits one who has erected permanent improveinents in good faith while in adverse possession under color of title to set off the value of such improvements against any damages that may be claimed by the owner. The right to compensation for improvements, beyond this very limited one of set-off, has, since an early date, consistently been denied by our courts. ${ }^{3}$

\section{Common Law Changed by Legislation in Most States}

While cases elsewhere can be found in support of a contrary doctrine, ${ }^{4}$ it must be admitted that the California decisions express the prevailing view, both at common law and equity, independently

I French Civil Code, $\S \S 566-577$. Cf. 1 Cal. Jur. 121, where the California Code provisions on accession are erroneously referred to as codifying the common law.

2 Eaton v. Langley (1898) 65 Ark. 448, 47 S. W. 123, 42 I. R. A. 474;

Isle Royale Mining Co. v. Hertin (1877) 37 Mich. 332, 26 Am. St. Rep. 520.

${ }^{3}$ Ford v. Holton (1885) 5 Cal. 319, 322; Yount v. Howell (1859) 14 Cal. 465; Huse v. Den (1890) 85 Cal. 390, 401, 24 Pac. 790; Kinard v. Kaelin (1913) 22 Cal. App. 383, 389, 134 Pac. 370.

4 Bright v. Boyd (1841) I Story, 478, Fed. Cas. No. 1,875; Parker v. Stevens (1820) 3 A. K. Marsh (10 Ky.) 197, 202; Union Hall Ass'n. v. Morrison (1873) 39 Md. 281; Hatcher v. Briggs (1876) 6 Ore. 31. 
of statute. ${ }^{5}$ As early as 1781 , however, a change was effected by legislation in one jurisdiction, ${ }^{6}$ and by the present time the laws of three-fourths of the states have abrogated the old common-law doctrine and made provision for compensation for the innocent improver of real property. ${ }^{7}$ Had it not been for the enactment of these statutes, generally known as betterment acts or acts for the protection of occupying claimants, it is not improbable that by the present time many more courts would have followed Justice Story's precellent in Bright $v$. Boyd $d^{8}$ and adopted the more just and equitable civil law rule without the aid of legislation.

Eramination of such compilations of the statutes of the various states as were available to the writer show the following fourteen, only, in which legislation of the type under discussion is apparently not in force: Arizona, California, Colorado, Delaware, Idaho, Maryland, Montana, Nevada, New Jersey, New York, Oregon, Pennsylvania, Rhode Island and Tennessee. Of these, however, Maryland and Oregon must be excluded, as the courts of these states are among the several which have been willing to allow compensation to the innocent improver independently of statute. ${ }^{\circ}$ An affirmative allowance for the value of improvements would, there-

5 See Woodward, The Law of Quasi Contracts, pp. 299-301 and cases cited. Where, however, the owner of the property for any reason seeks the assistance of a court of equity in the enforcement of his rights, it is generally recognized that the so-called "do equity" rule may be applied so as to require compensation to the imnocent improver as a condition of granting the equitable relief to the owner. See Woodward, op. cit., p. 300.

'Vermont. See Slade's State Papers, p. 442 ; referred to in Whitney v. Richardson (1858) $31 \mathrm{Vt} .300,307$.

'Ala. Civ. Code, 1907, \$\$ 3846-3849; Ark., Crawford \& Morse's 1921 Digest, § 3703 et seq.; Conn. Gen. Stats, 1918, § 5112; Fla. Rev. Gen. Stats. 1920, \& 3239 et seq.; Ga. Code, 1911, § 5587 et seq.; Ill. Rev. Stats. 1921, c. 45, $\$ 49$ et seq.; Ind., Burns' Ann. Stats. 1914, $\$ 1121$ et seq.; Iowa, Comp. Code, 1919 , \& 6406 et seq.; Kan. Gen. Stats. 1915, \& 7530 et seq.; Ky. Carroll's Stats. 1922, § 3728 et seq.; La. Civ. Code, § 3453; Me. Rev. Stats. 1916, c. 109, § 20 ; Mass. Gen. Laws, 1921, c. 237, \&16 et seq.; Mich. Comp. Laws, 1915, § 13210 et seq.; Minn. Gen. Stats. 1913, $\$ 8068$ et seq.; Miss., Hemmingway's Code, 1917 , \& 1481 et seq.; Mo. Rev. Stats. 1919 , \$ 1834 et seq.; Neb. Rev. Stats. 1913, § 6255 et seq.; New Mex. Ann. Stats. 1915, \& 4373 et seq.; N. H. Pub. Stats. 1901, c. $228, \$ 2$ et seq.; N. C. Consol. Stats. 1919, \& 699 et seq.; N. D. Comp. Laws, 1913, \& 8151 et seq.; Ohio Throckmorton's Gen. Code, 1915 , \& 11907 et seq.; Okla. Rev. Laws, 1910, $\$ 4933$ et seq.; S. C. Code of Laws, 1912 , Civ. Code, $\$ 3526$ et seq.; S. D. Rev. Code, 1919, \& 2857 et seq.; Tex. Comp. Stats. 1920, Art. 7760 et seq.; Utah Comp. Laws, 1917, § 5031 et seq.; Vt. Gen. Laws, 1917, § 2131 et seq.; Va. Code, 1919, § 5491 et seq.; Wash. Rem. \& Bal. Codes \& Stats. 1910, \$ 797 et seq.; W. Va., Barnes Code,

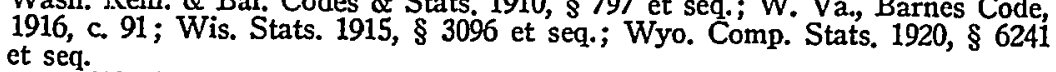

8 (1841) 1 Story, 478, Fed. Cas. No. 1, 875; see also s. c. (1843) 2 Story, 605, Fed. Cas. No. 1, 876 .

${ }^{9}$ See cases cited, supra, n. 4. 
fore, be denied the innocent improver in not more than twelve of the forty-eight states. Furthermore, in these twelve, with the exception of California, New Jersey, New York, Pennsylvania and Tennessee, the question has apparently never been definitely settled, so that it is possible that the courts of some, or all, of these other seven states might follow the doctrine of Bright v. Boyd. In the five states mentioned, the law would seem to have been established against the granting of any affirmative relief to the improver. Mention has already been made of the California decisions. ${ }^{10}$ At one of the early sessions of the California legislature, in 1856, a statute was enacted designed to give relief to occupants who had made improvements. ${ }^{11}$ Unfortunately the provisions of this statute were somewhat broader than was necessary and broader than like provisions in other states, and the act was held unconstitutional by the California Supreme Court the following year. ${ }^{12}$ Further reference to this decision will be made later. In New York and New Jersey the statutory provisions permitting the value of improvements to be set off against any damages claimed by the owner contain the positive restriction "but not beyond the amount of those damages." 13 In Pennsylvania it has been judicially decided that except as to land claimed under tax sales, express provision as to which is made by statute, no right to an allowance for the value of improvements exists beyond that of set-off against the owner's claim for damages and mesne profits. ${ }^{14}$ Tennessee stands alone in holding that the legislature cannot constitutionally give the innocent improver any affirmative relief beyond this right of set-off. ${ }^{15}$

The statutes in force in the thirty-four states, while differing considerably in wording, very closely resemble each other in substantial effect. Provision is generally made for the assessment of the benefits and the awarding of compensation as a part of the proceedings in ejectment, and no independent action on the part of

10 Supra, n. 3.

11 Act of March 26, 1856; Cal. Stats. 1856, p. 54.

12 Billings v. Hall (1857) 7 Cal. 1.

13 New Jersey Comp. Stats. 1709-1910, v. 2, p. 2063, § 47; Parson's New York Code of Civil Procedure, 1920, § 1531. Such a statute would not, of course, definitely preclude a court of equity from giving independent relief to the improver, under the doctrine of Bright v. Boyd; but the particular wording would probably be interpreted as a manifestation of legislative intent that the relief to the improver should be thus limited. There is, moreover, a New York decision holding expressly contra to the rule of Bright v. Boyd. Putnam v. Ritchie (1837) 6 Paige Ch. (N. Y.) 390.

14 Putnam v. Tyler (1888) 117 Pa. St. 570, 12 Atl. 43.

15 See Tennessee cases cited, n. 30, infra. 
the improver is provided for. ${ }^{16}$ Nearly all of the statutes give the owner of the land the option either to pay for the improvements and recover possession or to sell the land to the improver at its value with the improvements excluded. ${ }^{17}$ Almost uniformly they require good faith or the part of the improver as a condition to the existence of his right to relief. ${ }^{18}$

\section{Reguirement of Color of Title}

In addition to good faith, a majority of the enactments provide that the improver shall have acted under color of title. The desirabihty of this requirement may well be doubted. It excludes from those entitled to relief persons who in good faith have erected improvernents under a mistake as to the identity or location of the land. It is not impossible to conceive of a case where such a mistake might have been made without the slightest imputation of negligence on the part of the improver. Furthermore, as has been said in passing upon at somewhat analogous question, "good faith . . . is not incompatible with some degree of negligence."19 It would seem neither just nor desirable to deny compensation in all cases of mistaken location. This view finds support in the statutes of a number of the

16 The New Mexico statute provides for the assessment of benefits and the awarding of compensation either in the ejectment proceedings or "by an appropriate action" instituted at any time within ten years after the improver has been deprived of possession. N. Mex. Ann. Stats. 1915, \& 4375. It would seem, however, that the instances would be rare where the improver would lose possession otherwise than through legal proceedings instituted by the owner.

17 A.n act amendatory of the original Ohio statute and giving this option to the clccupant instead of to the owner was held unconstitutional in McCoy v. Grandy (1854) 3 Ohio St. 463.

${ }_{18}$ A.lthough the Nebraska act apparently did not specify good faith as a condition to the right to compensation for improvements, the Supreme Court of that state seems to have held it requisite. Carter v. Brown (1892) $35 \mathrm{Neb}$. 670,53 N. W. 580 . The Alabama statute, Civ. Code, 1907, §§ 3846-3849, also makes ro mention of good faith on the part of the improver, but does contain the requirement, not found in most acts, that there should be three years adverse possession. Massachusetts has a similar provision, not requiring good faith where there has been possession for six years, but making it essential where the possession has been for a shorter period. Mass. Gen. Laws, 1921, c. $237, \S \S 16,17$.

${ }^{19}$ Lowell, $J .$, in Trustees of Dartmouth College v. International Paper Co. (C.C., D.N.H.,1904) 132 Fed. 92. The question there presented was whether or not a converter of personal property could be held to have acted in good faith and therefore entitled to have damages assessed against him on the lowest basis, i.e., on the value of the property in its original state, prior to his improvement of it. 
states, in which no requirement of color of title is made, ${ }^{20}$ and it has been omitted in the proposed California statute hereinafter set forth.

\section{REIMBURSEMENT FOR TAXES}

A number of the statutes make provision for the reimbursement of the occupant for taxes and assessments which he has paid, ${ }^{21}$ as well as for improvements erected, but in the majority of instances improvements, only, are mentioned. Where the owner has not also paid the same taxes, ${ }^{22}$ the justice of an allowance to the occupant for such payment would seem to be as great as for improvements. Provision to this effect has been made in the proposed statute.

\section{Protection for Mortgagee of IMPRover}

A situation apparently not provided for by any of the statutes in force in other states but which might frequently occur is that created by the existence of a mortgage on the premises executed by the improver. In the event that the owner elects to compensate him for the improvements and recover the property, should not the mortgagee receive the benefit of such compensation? An analogy in the law of mortgages may be found, pursuant to which relief might possibly be given independently of express provision in the statute. A junior mortgagee who has been brought into court on the foreclosure suit of a senior mortgagee but who has not by cross-complaint sought to foreclose his own mortgage, is, nevertheless, entitled to a provision in the decree for the application of any surplus resulting from the foreclosure sale in reduction of the indebtedness to him..$^{28}$ In a jurisdiction such as California where third parties are accorded the privilege of intervening wherever their rights are affected, ${ }^{24}$ the courts might possibly feel warranted in giving a mortgagee who intervened rights against the fund to be paid as compensation for the improvements erected by the mortgagor. It would seem preferable, however, to make express provision for such protection in the statute itself.

20 Alabama, Connecticut, Georgia, Maine, Massachusetts, Missouri, New Hampshire, Texas, Virginia, West Virginia. For references to the statutes of these states, see, supra, n. 7.

21 E. g., \$ 797 Rem. \& Bal. Wash. Codes \& Stats. 1910.

22 Instances of such double payment, of course, occasionally occur. See, e. g., Owsley v. Matson (1909) 156 Cal. 401, 104 Pac. 893; Cummings v. Laughlin (1916) $173 \mathrm{Cal} .561,160$ Pac. 833.

23 Jones on Mortgages (7th ed.) \$1688a; Ward v. McNaughton (1872) $43 \mathrm{Cal} .158,161$; Camp v. Land (1898) $122 \mathrm{Cal} .167,170,54 \mathrm{Pac} .839$.

24 Cal. Code Civ. Proc. \$ 387. 


\section{Time Allowed for Payment}

The time allowed for payment by the plaintiff of the value of the improvements, or by the defendant of the value of the land without the improvements, of course differs under the various enactments. By some statutes it is left to the court in each case to fix a reasonable time within which payment shall be made. ${ }^{25}$ By others the time is definitely fixed, as, within three nonths, ${ }^{26}$ or within one year, ${ }^{27}$ after the amount has been determined. In others provision is made for payment in two ${ }^{28}$ or three ${ }^{29}$ annual installments. Opinions may reasonably differ as to which is the preferable provision in this regard, but this is a relatively minor matter of detail.

\section{Constitutionality of Statute}

The constitutionality of legislation providing for compensation for improvements has frequently been challenged but very generally upheld..$^{30}$ The Supreme Court of the Umited States has apparently never rendered a direct decision upon the question. In an early case, Green v. Biddle, ${ }^{81}$ decided in 1823, the court held the Kentucky betterment act to be violative of the compact between Kentucky and Virgiria and therefore unconstitutional under article I, section 9 of the Constitution of the United States, prohibiting a state from passing a law impairing the obligation of contracts. Although the court made no pronouncement as to the validity of such legislation gener-

25 'Throckmorton's Gen. Code of Ohio, 1921, \$§ 11915-11917.

26 Jemmingway's Miss. Code, 1917, § 1481.

27 IMinn. Gen. Stats. 1913, $\$ \$ 8072-3$.

28 ]rla. Rev. Gen. Stats. 1920, $\$ \S 3244-5$.

29 IMass. Gen. Laws, 1921, c. $237, \S 33$.

30 Griswold v. Bragg (C.C.,D.Conn.,1880) 48 Fed. 519; Leighton v. Young (C.C.A.,8th C.,1892) 52 Fed. 439; Ross v. Irving (1852) 14 Ill. 171; Armstrong v. Jackson (1825) I Blackf. (Ind.) 374; Childs v. Shower (1865) 18 Iowa, 261; Madland v. Benland (1878) 24 Minn. 372; McCoy v. Grandy (1854) 3 Ohio St. 463; Barker v. Owen (1885) 93 N. C. 198; Lumb v. Pinckney (1884) 21 S. C. 471; Scott v. Mather (1855) 14 Tex. 235; Pacquette v. Pickness (1865) 19 Wis. 219; also cases cited in n. 35, infra. Apparently Tennessee is the only jurisdiction which has held legislation providing for compensation for improvements made by occupants in good faith unconstitutional regardless of any particular objectionable provision. See Nelson v. Allen (1830) 1 Yerger '(9 Tenn.) 360; McKinly v. Holliday (1837) 10 Yerger (18 Tenn.) 477. In Childs v. Shower and McCoy v. Grandy, supra, particular amendatory acts were held invalid but the constitutionality of the main legislation was affirmed.

${ }^{31} 21$ U. S. (8 Wheat.) 1, 5 L. Ed. 547. One of terms of the compact was "that all private rights and interests of lands . . shall be determined by the laws now existing in this state [Virginia]." At tbat date (1789) Virginial had no law providing for compensation for the innocent improver. 
ally, the language used in the opinions rendered by Justices Story and Washington might indicate that they did not look with favor upon that type of statute. Justice Story seems to have evidenced such dislike more clearly in an earlier decision in the Circuit Court, ${ }^{312}$ in which he held that a New Hampshire betterment statute, if construed to provide for compensation for improvements made prior to its enactment, was violative of an express provision of the constitution of that state inhibiting retrospective legislation. In decided contrast with this earlier attitude of lack of sympathy, if not hostility, are his subsequent views as set forth in Bright $\mathrm{v}$. Boyd, ${ }^{32}$ where he speaks of the innocent improver's claim for compensation as founded on most persuasive equity, common sense and common justice.

Any doubt as to the attitude of the Supreme Court on the question of constitutionality should be set at rest, by the following very pointed dictum of Chief Justice Fuller in Searl v. School District ${ }^{33}$ :

"The civil law recognized the principle of reimbursing to the bona fide possessor the expense of his improvements if he was removed from his possession by the legal owner, by allowing him the increase in the value of the land created thereby. And the betterment laws of the several states proceed upon that equitable view. The right of recovery, where the occupant in good faith believes himself to be the owner, is declared to stand upon a principle of natural justice and equity, and such laws are held not to be unconstitutional as impairing vested rights, since they adjust the equities of the parties as nearly as possible according to natural justice; and in its application as a shield of protection, the term 'vested rights' is not used in any narrow sense, but as implying a vested interest of which the individual cannot be deprived arbitrarily without injustice."

The question also arises as to the validity of legislation applying retroactively, i.e., providimg compensation for improvements made prior to its enactment. This seems to have been one of the grounds of objection to the California statute of 1856 , held unconstitutional by a divided court, in the case of Billings v. Hall. ${ }^{34}$ It is not clear, however, that the two justices who formed the majority in that case would not have upheld the act had it distinguished between occupants in good faith and in bad faith. The failure to make such a distinction appears to have been the chief ground of objection, as

31a Society for the Propagation of the Gospel v. Wheeler (1814) 2 Gall. 105, Fed. Cas. No. 13,156.

32 Supra, n. 4.

sa (1890) 133 U. S. 553, 561, 33 I. Ed. 740, 10 Sup. Ct. Rep. 374.

34 Supra, n. 13. 
more particularly appears from the dissenting opinion of Justice Terry. The majority of the decisions in other states, moreover, hold such legislation constitutional even as to improvements already existing. ${ }^{215}$ That there is no general principle making legislation void because it is retrospective has frequently been recognized by the Supreme Court of the United States. ${ }^{36}$ In expressing his views on the constitutionality of the statutes here under discussion Judge Cooley says: ". . . a statute cannot be void as an unconstitutional interference with private property which adjusts the equities of the parties as nearly as possible according to natural justice." Referring in particular to the question of retroactivity he states: "The principle of equity upon which such legislation is sustained would seem not to depend upon the time when the improvements were made." ${ }^{37}$

\section{Suggested California Statute}

Since section 741 of the Code of Civil Procedure now provides that the value of improvements may be set off against any damages claimed for withholding the property, it would seem proper for any more general provision for compensation to follow this section and form a portion of the sane chapter of the code relating to actions concerning real property. A proposed form of statute, designated by the new section numbers $741 \mathrm{a}$ to $741 \mathrm{f}$ inclusive, is given herewith:

741a. In all actions hereafter to be commenced or hereafter to be trie:d for the recovery of real property the defendant may, in addition to, or in lieu of, denying the plaintiff's right thereto, set up in his answer that he, or those under whom he claims, holding adversely to the claim of the plaintiff, in good faith made permanent improvements on said real property or paid taxes or assessments thereon, legally due and not also paid by the plaintiff or those under whom he claims, and may ask to have the value of said improvements or

${ }^{35}$ Fee v. Cowdry (1885) 45 Ark 410; Mills v. Geer (1900) 111 Ga. 275, 36 S. ]E. 673, 52 L. R. A. 934; Claypoole v. King (1879) 21 Kan. 602; Davis' Lessee v. Powell (1844) 13 Ohio, 308 (statute held to be retrospective in its effect, but no discussion of constitutionality); Whitney v. Richardson (1858) $31 \mathrm{Vt}$. 300. In Bacon v. Callender (1810) 6 Mass. 303 and Brackett v. Norcross (1820) $1 \mathrm{Me}$. 89, it was held as competent for the legislature to make the statutes applicable to pending actions as to those subsequently commenced. In two jurisdictions, however, it has been held that it would not be constitutional for the statutes to apply to improvements made prior to their enactment. Newton v. Thornton (1885) 3 N. Mex. 287, 5 Pac. 257; Investment Co. v. Hambach (1905) 37 Wash. 629, 80 Pac. 190.

${ }^{36}$ Curtis v. Whitney (1871) 80 U. S. (13 Wall.) 68.

37 Cooley, Constitutional Limitations (7th ed.) p. 553. 
the amount of said taxes or assessments determined and compensation awarded to the defendant for the same.

$741 \mathrm{~b}$. In the event that the court or jury find that the plaintiff is entitled to said real property but that the defendant, or those under whom he claims, holding adversely to the claim of the plaimtiff, in good faith made permanent improvements on said property, or paid taxes or assessments thereon legally due and not also paid by the plaintiff or those under whom he claims, it shall be the duty of said court or jury also to ascertain and assess:

1. The value of the property at the time of the assessment, irrespective of the permanent improvements made thereon by the defendant, or by those under whom he claims.

2. The amount paid by defendant or by those under whom he claims in taxes or assessments legally due and not also paid by the plaintiff, or by those under whom he claims, and the value at the time of the assessment of the permanent improvements made by the defendant, or by those under whom he claims.

3. The value of the use and occupation of the property, without said improvements, during the period of the defendant's possession thereof, and the amount of damage, if any, done to said property by the defendant.

741c. If the amount assessed under subdivision three of section $741 \mathrm{~b}$ shall equal or exceed the amount assessed under subdivision two thereof, the plaintiff shall be entitled to have judgment entered in his favor for the possession of the property and also to have judgment entered against the defendant for the payment of the difference, if any, between the two said amounts. If the amount assessed under subdivision three shall be less than the amount assessed under subdivision two, judgment shall be entered in the alternative, i.e. that the plaintiff shall recover possession of the property upon paying to the defendant the difference between said amounts, or that the plaintiff shall permit the defendant to retain the property upon payment to the plaintiff of the value thereof as assessed under subdivision one.

741d. The plaintiff shall within 90 days after the entry of such judgment, or if an appeal from such judgment shall have been taken, within 30 days after such judgment shall have become final, either pay to the defendant the difference betwen the amount assessed under subdivision two and that assessed under subdivision three of section $741 \mathrm{~b}$, in which event he shall be entitled to immediate possession of the property, or file with the court and serve upon the defendant or his attorney notice of his election to pernit the defendant to retain 
the property upon payment to the plaintiff of the value thereof as assessed under subdivision one of section 741b. Upon service of such notice the defendant shall have 90 days within which to pay to the plaintiff the value of the property so assessed. If such payment be not made within said period of 90 days the plaintiff shall be entitled to immediate possession of the property. In the event of the plaintiff's failure to elect between the two alternatives as hereinbefore provided, the defendant may within 90 days after the expiration of the time limited for plaintiff's election pay to the plaintiff the value of the property assessed under subdivision one of section $741 \mathrm{~b}$ and retain the property.

741e. In the event of the failure of both plaintiff and defendant to exercise their election within the time herein provided, they shall be deemed tenants in common of the property including the improvements, in the proportion which the amount assessed under subdivision one of section $741 \mathrm{~b}$ bears to the difference between the amount assessed under subdivisions two and three thereof, and the court shall enter a supplemental judgment or decree so declaring. Upon proof of the election having been fully made and consummated as hereinbefore: provided, the court shall enter a supplemental judgment or decree finally awarding the property to the plaintiff or the defendant, as the case may be.

741f. Where the property is subject to a mortgage or deed of trust made by the defendant, or by those under whom he claims, the person to whom the debt secured by said mortgage or deed of trust is to be paid may intervene in the action to recover possession of the: property and may prove such mortgage or deed of trust and the annount of the debt secured thereby, and in the event that the plaintiff elects to recover possession of the property upon paying the difference between the ainount assessed under subdivision two and that assessed under subdivision three of section $741 \mathrm{~b}$, such payment shall, up to the amount of such indebtedness, be made to the intervener in reduction of such indebtedness, whether the same shall be then due or not, and the balance, if any, shall be paid to the defendant.

School of Jurisprudence,

$$
\text { W. W. Ferrier, Jr. }
$$

Univer'sity of California. 